\title{
A GOMPARISON BETWEEN THE MODERN AND GOMPOSITE PLEISTOCENE SNOW-LINES, ABSAROKA AND BEARTOOTH MOUNTAINS, MONTANA-WYOMING, U.S.A.
}

\author{
By Thomas T. Zwiak \\ (Department of Physical Sciences, Eastern Montana College, Billings, Montana 59ror, \\ U.S.A.)
}

\begin{abstract}
The modern and composite Pleistocene snow-lines of the Absaroka and Beartooth Mountains, Montana-Wyoming, were established from a population of 135 north-facing cirques and cirque glaciers distributed across Boulder River, Stillwater River, Rosebud, and Rock Creeks. The 3 r ro m elevation of the modern snow-line was established by connecting the accumulation-area ratios of 35 existing cirque glaciers. The composite Pleistocene snow-line was established by joining the mean floor elevations of the lowest abandoned cirques.

Comparison of the modern and composite Pleistocene snow-lines indicates that the composite Pleistocene snow-line was depressed, at minimum, $305 \mathrm{~m}$ during the Pleistocene. The $305 \mathrm{~m}$ depression suggests that the mean Pleistocene temperatures were, at a minimum, 1.9 deg lower than the present mean annual temperatures found in the study area.

Both the modern and Pleistocene snow-lines slope towards lower elevations in the Boulder and Stillwater drainages than in the Rosebud-Rock Creek drainages. Modern precipitation rates also show greater precipitation in the Boulder-Stillwater drainages than the Rosebud-Rock Creek drainages. The parallelism of the modern and composite Pleistocene snow-lines, and present precipitation rates suggest that temperature rather than precipitation is the controlling factor causing the depression of the snow-lines.

The distribution of cirque elevations indicates that snow-lines fluctuated a minimum of four times during the Pleistocene.
\end{abstract}

RÉsumÉ. Une comparaison entre les lignes de névé actuelle et pleistocène dans les Absaroka et Beartooth Mountains, Montana-Wyoming, U.S.A. On a établi les niveaux moderne et pleistocène des lignes de névés dans les Absaroka et Beartooth Mountains dans le Montana-Wyoming, en utilisant 135 cirques orientés au Nord et glaciers de cirques distribués dans les vallées de la Boulder River, Stillwater River, de Rosebud et de Rock Creeks. Les $3110 \mathrm{~m}$ d'altitude de la ligne de névé actuelle ont été établis en comparant les rapports accumulation/ablation de 35 glaciers de cirques existants. La ligne de névé au pleistocène a été établie en joignant les altitudes moyennes du fond des cirques abandonnés les plus bas.

La comparaison des lignes de névé actuelle et au pleistocène indique que la ligne de névé au pleistocène était abaissée d'au moins $305 \mathrm{~m}$ par rapport au niveau actuel. Cet abaissement révèle que la température moyenne au pleistocène était d'au moins 1,9 deg inférieure à la température moyenne annuelle actuelle observée dans la zone d'étude.

Les lignes de névé actuelle et pleistocène sont à des altitudes plus faibles dans les bassins versants de Boulder et de Stillwater que dans ceux de Rosebud et de Rock Creeks. Le parallélisme des lignes de névé actuelles et pleistocène et le taux actuel de pluviométrie font penser que la température plus que les précipitations sont le facteur déterminant l'abaissement de la ligne de névé.

La distribution des altitudes des cirques indique que les lignes de névé ont varié au moins quatre fois pendant le pleistocène.

Zusammenfassung. Ein Vergleich zwischen der derzeitigen und der abgeleiteten pleistozänen Schneegrenze in den Absaroka und Beartooth Mountains, Montana-Wyoming, U.S.A. Die derzeitige und die abgeleitete pleistozäne Schneegrenze in den Absaroka und Beartooth Mountains, Montana-Wyoming, wurde aus einer Gruppe von I 35 nord-exponierten Karen und Kargletschern bestimmt, die über Boulder River, Stillwater River, Rosebud und Rock Creeks verteilt sind. Die Höhe von 3 i 10 m für die derzeitige Schneegrenze ergab sich aus der Verbindung der Flächenverhältnisse des Akkumulationsgebietes von 35 bestehenden Kargletschern. Die pleistozäne Schneegrenze wurde als Verbindungslinie der mittleren Bodenhöhen in den tiefsten verlassenen Karen bestimmt.

Der Vergleich zwischen beiden Schneegrenzen ergibt eine Depression der pleistozänen Schneegrenze um mindestens $305 \mathrm{~m}$. Daraus lässt sich schliessen, dass die mittlere Temperatur im Pleistozän mindestens I,9 deg niedriger war als die derzeit herrschende mittlere Jahrestemperatur im Untersuchungsgebiet.

Beide Schneegrenzen sinken im Boulder- und Stillwater-Einzugsgebiet tiefer ab als im Rosebud-Rock Creek-Einzugsgebiet. Die derzeitigen Niederschlagsmengen sind entsprechend im ersten Einzugsgebiet grösser als im zeiten. Diese Parallelität zwischen den beiden Schneegrenzen und den derzeitigen Niederschlagsmengen lässt annehmen, dass die Temperatur eher der entscheidende Faktor für die Schneegrenzdepression war als der Niederschlag.

Die Verteilung der Karhöhen zeigt, dass die Schneegrenze sich im Pleistozän mindestens viermal verändert. 


\section{INTRODUCTION}

The technique of reconstructing Pleistocene snow-lines based on the mean floor elevations of independent cirques has been employed successfully by Flint $\left(\left[{ }^{\mathrm{c}} \mathrm{I} 97 \mathrm{I}\right]\right)$, Miller $\left(\left[{ }^{\mathrm{c}} \mathrm{I} \mathrm{g}^{6} \mathrm{I}\right]\right)$, and Porter (I964). Composite Pleistocene snow-lines as defined by Flint $\left(\left[{ }^{\mathrm{C}} \mathrm{I} 97 \mathrm{I}\right]\right)$ are snowlines reconstructed by using the elevation of cirque floors which have been repeatedly glaciàted. Composite Pleistocene snow-lines in this paper will conform to Flint's definition. Reconstructed composite Pleistocene snow-lines, when compared to modern regional snowlines, provide a way of estimating Pleistocene paleoclimatic variances in temperature and precipitation.

\section{LOGATION AND DESCRIPTION OF THE STUDY AREA}

The study area encompasses that part of the Absaroka Range and the Beartooth Mountains lying north of Yellowstone National Park (Fig. I, inset). The area is bounded by the upper Yellowstone River to the west and north, and the Clark Fork of the Yellowstone River on the east.

Topographic elevations within the study area range from $1707 \mathrm{~m}$ near the city of Red Lodge to $3901 \mathrm{~m}$ at Granite Peak. Granite Peak is the highest topographic elevation in the State of Montana.

The general geology of the study area consists dominantly of metamorphic and granitic rocks of Precambrian age. The Precambrian rocks are cut by a series of Tertiary basic intrusive dikes and, in some places, are overlain by Tertiary volcanic rocks.

\section{Methods OF STUdy AND INTERPRETATION OF RESULTS}

A population of 135 north-facing cirques was selected at random from four major drainage basins within the study area. The drainage basins (Fig. I) were the Boulder River, Stillwater River, Rosebud Creek, and Rock Creek from west to east, respectively.

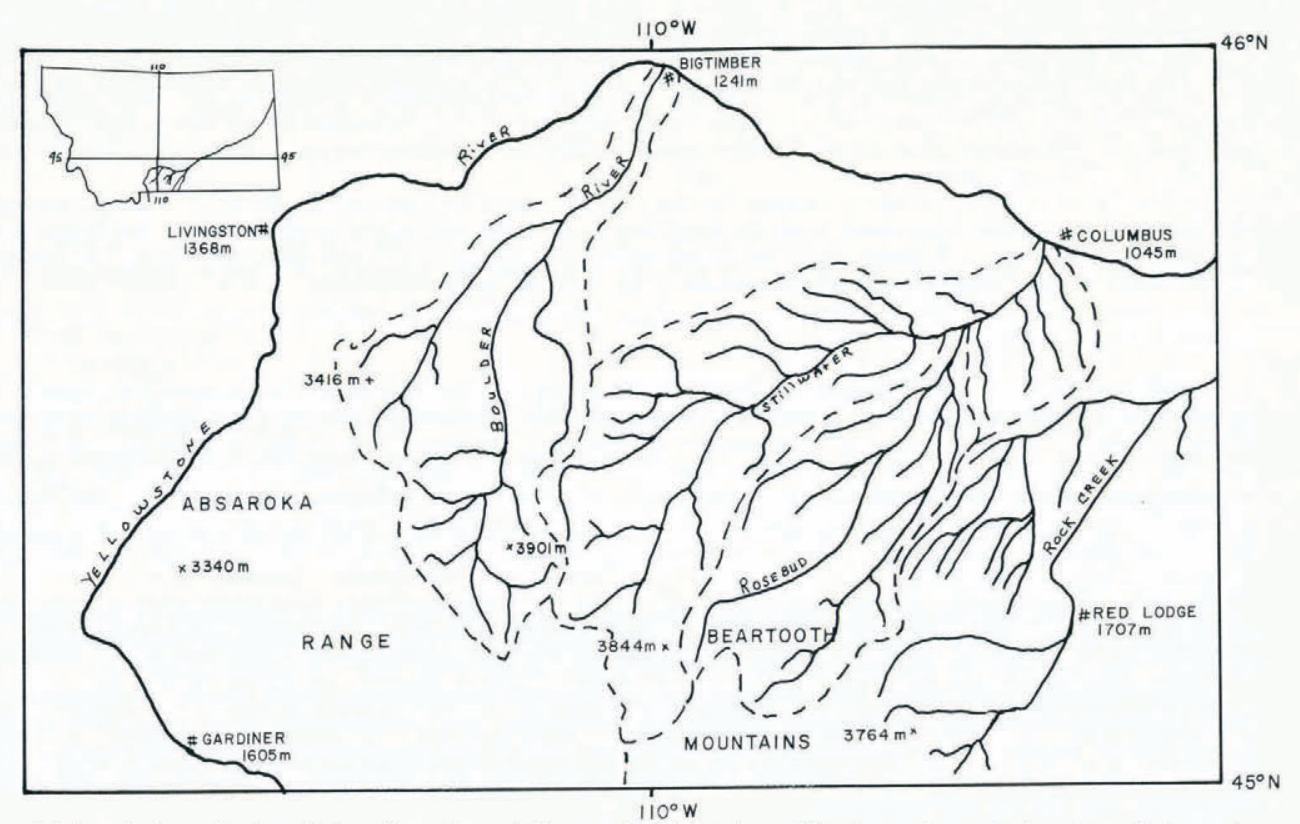

Fig. 1. Major drainage basins of the Absaroka and Beartooth Mountains. The inset shows the location of the study area. 
The identification and location of cirques was determined from aerial photographs, obtained from the U.S. Forest Service, and on topographic maps. The mean elevations of the cirque floors were calculated from aerial photographs by using a parallax bar and were field checked with a Paulin altimeter. The mean elevation of each cirque floor was defined as that elevation occurring where the headwall meets the cirque floor, or as the surface elevation of the tarn if such existed in the cirque. The distribution of cirque floors was found to conform to four distinct elevations. The four levels of cirque development are found at $2743,2835,2926$, and $3048 \mathrm{~m}$ in the Boulder and Stillwater drainages and at 2926 , 3 048, 3170 , and $3353 \mathrm{~m}$ in the Rosebud and Rock Creek drainages (Fig. 2). Cirques existing above 3 r r $\mathrm{m}$ constitute abandoned cirques above the modern snow-line elevation. The lowest composite Pleistocene snow-line was established as that plane defined by joining the elevations of the lowest ice-free cirque floors in each of the drainage basins located in the study area (Fig. 3). Flint (197I) indicated that the snow-line during the initial phases of cirque development approximates the cirque-floor elevations.

The mean elevation of the modern regional snow-line was established using the area accumulation ratio (AAR). The AAR is calculated according to the following formula:

$$
\text { Area accumulation ratio }=\frac{\text { accumulation area }}{\text { total area }} .
$$

The accumulation area is defined as that zone on a glacier above which $60 \%$ or more of the glacier's area is covered by snow at the end of the ablation season. This zone is also correlative with the elevation of the regional snow-line where it crosses the glacier. The regional snow-line elevation for an alpine system may be established by connecting the AAR zones of the existing glaciers. Thirty-five existing glaciers establish the modern snow-line in the study area at an elevation of 3 I $10 \mathrm{~m}$. A comparison of the modern regional snow-line

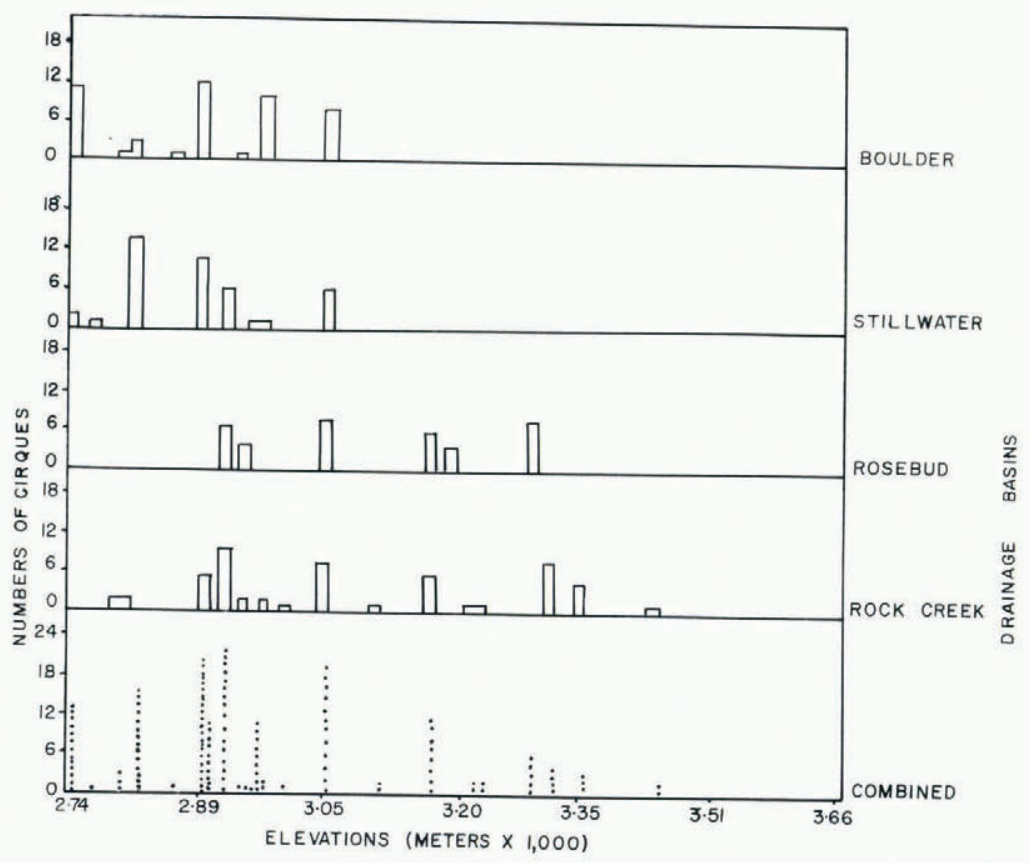

Fig. 2. Distribution of north-facing Pleistocene cirques in selected drainage basins of the Absaroka and Beartooth Mountains, Montana-Wyoming. 


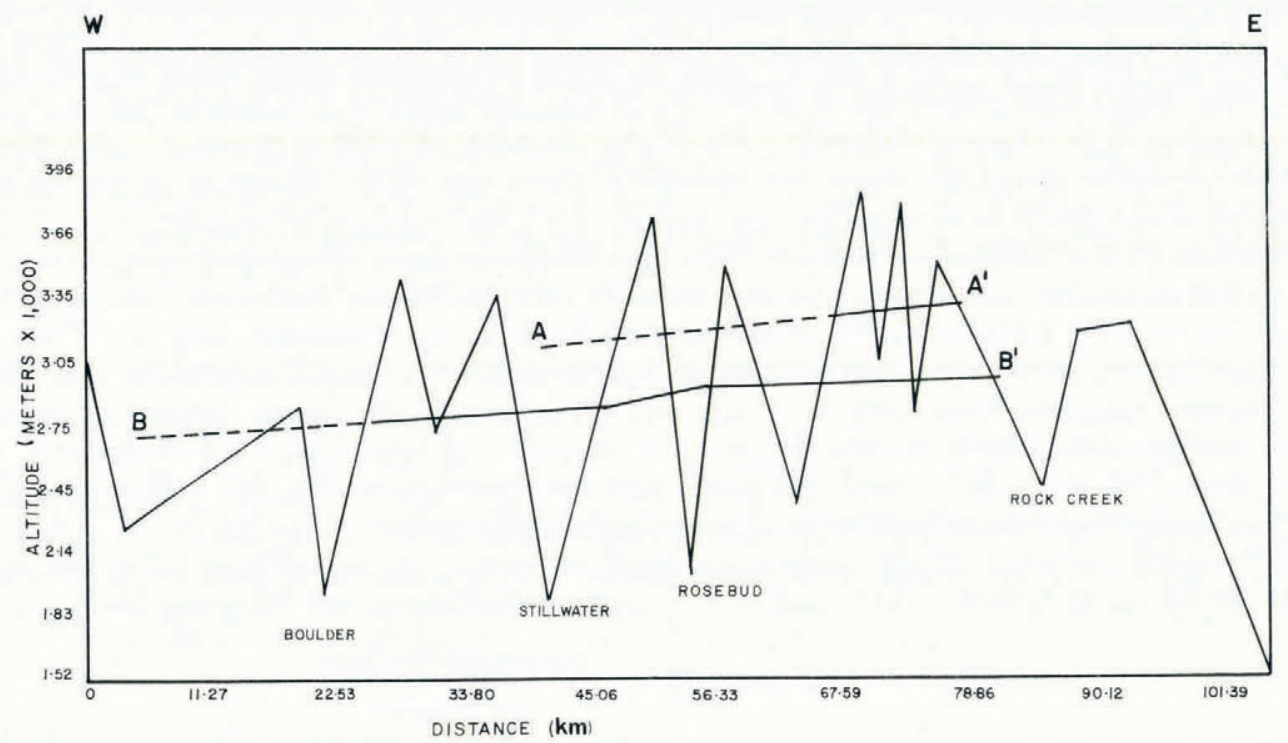

Fig. 3. Comparison between the altitudes of the modern regional snow-line $\left(A-A^{\prime}\right)$ and the lowest composite Pleistocene snow-line $\left(B-B^{\prime}\right)$.

with the lowest composite Pleistocene snow-line (Fig. 3) showed a parallelism of slopes with both snow-lines existing at higher topographic elevations in the Rock Creek drainage and at lower elevations in the Boulder River drainage.

The lowest composite Pleistocene snow-line is depressed approximately $305 \mathrm{~m}$ lower than the modern regional snow-line across the four drainage basins. The depression of a snow-line is a function of temperature and precipitation as indicated by Paschinger (1912). The depression of the snow-line may also be a result of increased precipitation rates. The depression of the snow-lines to lower elevations in the Boulder-Stillwater drainages suggests that more precipitation occurs here than in the Rosebud-Rock Creek drainages. Modern snow-pack rates established over a 20 year period by the U.S. Soil Conservation Service and the U.S. Forest Service show the Boulder River to receive $53.21 \mathrm{~cm}$ (water equivalent), while Rock Creek receives $42.55 \mathrm{~cm}$. Modern precipitation patterns result from orographic lifting of moisture-laden air masses moving eastward across the study area. These air masses originate in the Maritime Polar source region located off the U.S.-Canadian Pacific Coast and travel eastward across the study area. The depression of the Pleistocene and modern snow-lines to lowest levels in the Boulder-Stillwater drainage indicates that the wind and precipitation patterns have not changed appreciably from the Pleistocene to modern time but have been somewhat constant. The parallelism of the modern and Pleistocene snow-lines suggests that temperature rather than precipitation is the controlling factor causing the depression of the snow-lines. Applying a normal lapse-rate of $6.4 \mathrm{deg} \mathrm{km}{ }^{-1}$ of elevation (Donn, [ $\left.{ }^{\mathrm{c}} \mathrm{I} 975\right]$ ) to the $305 \mathrm{~m}$ depression of the composite Pleistocene snow-line, indicates that mean Pleistocene temperatures were, at a minimum, I.95 deg lower than the present mean temperatures found in the study area. This difference in mean annual temperatures agrees with Pleistocene temperature depressions for the western United States that were determined by Louis and Klute (Reeves, I965[a], [b]).

The distribution and elevations of cirque floors throughout the study area are shown in Figure 2. An analysis of variance test on the distributions of the cirque-floor elevations across the Boulder-Stillwater and Rosebud-Rock Creek drainage basins shows the variation in cirque levels to be significant to the o.or level. 
TABle I. Summary table For the ANAlysis of VARiance

$\begin{array}{lcccc}\begin{array}{l}\text { Source of } \\ \text { variation }\end{array} & \begin{array}{c}\text { Degrees of } \\ \text { freedom }\end{array} & \begin{array}{c}\text { Sums of } \\ \text { squares }\end{array} & \begin{array}{c}\text { Mean } \\ \text { squares }\end{array} & \begin{array}{c}\text { Calculated } \\ \text { F value }\end{array} \\ \text { Between groups } & 3 & 15.806 & 5.268 & 33.13 \\ \text { Within groups } & 132 & 21.046 & \text { 0.159 } & \\ \text { Total } & 135 & 36.852 & & \end{array}$

Significant $F$ value: $F$ (o.or) degrees of freedom 3, I $32=3.78$.

The cirque-floor elevations were then subjected to a Scheffe test for all possible comparisons (Roscoe, 1975). The results of the Scheffe test indicate that the mean cirque-floor elevations of the Boulder-Stillwater drainages are significantly lower than those in the Rosebud-Rock Creek drainages (Table II).

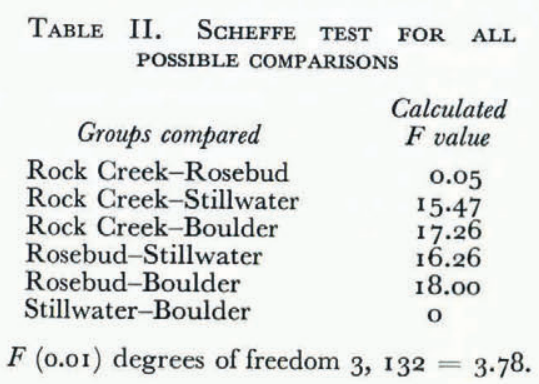

This distribution strongly suggests that the four levels of cirque development found in the Boulder, Stillwater, Rosebud, and Rock Creek drainages indicate that the regional snow-line fluctuated a minimum of four times during the Pleistocene.

Cirque levels higher than the modern snow-line suggest complete deglaciation during the thermal maxima and a re-appearance of small glaciers during the Little Ice Age or Neoglaciation. Graf (1976), using length-width and length-height ratios, has shown that glacierized cirques in the Beartooth Mountains are larger in size than abandoned cirques having the same elevations and orientations. The abandoned cirques typically have steep narrow sides and shallow depths. The presence of abandoned cirques existing above the modern snow-line suggests that the geometry of the cirque does not allow it to catch the amount of snow required for glacier formation under modern climatic conditions. The geometry of the cirque may not have been such a critical factor during the Neoglaciation when temperatures were cooler. The lowering of temperature during the Neoglaciation would have allowed an accumulation of snow under the present precipitation rates.

\section{Summary AND GONGLUSIONS}

The distribution of cirques in the Absaroka and Beartooth Mountains indicates that a minimum of four major fluctuations of the snow-line occurred during the Pleistocene. A comparison of the composite Pleistocene snow-line and the modern regional snow-line showed a depression of $305 \mathrm{~m}$ of the Pleistocene snow-line. This depression of the Pleistocene snow-line resulted in a lowering of the mean annual Pleistocene temperature a minimum of I.95 deg. The parallel relationship found to exist between the modern regional and Pleistocene snow-lines indicates that changes in mean annual temperatures were the major factor resulting in the lowering of the Pleistocene snow-line. The slope of the snow-line suggests that sources of moisture and air-mass flow patterns during the Pleistocene did not differ appreciably from those of the present. 
The depression of the Pleistocene snow-line and cirque development in the Absaroka and Beartooth Mountains is apparently the result of a lower mean annual temperature.

MS. received 12 April 1979 and in revised form 5 November 1979

\section{REFERENCES}

Donn, W. L. [ ${ }^{\mathrm{c}}$ I975.] Meteorology. Fourth edition. New York, etc., McGraw-Hill Book Co., Inc.

Flint, R. F. [c ${ }_{1}$ 971.] Glacial and Quaternary geology. New York, John Wiley and Sons, Inc.

Graf, W. L. 1976. Cirques as glacier locations. Arctic and Alpine Research, Vol. 8, No. I, p. 79-9o.

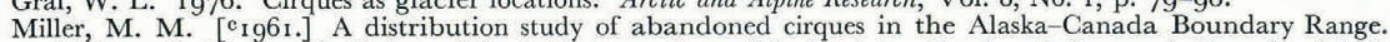
(In Raasch, G. O., ed. Geology of the Arctic: proceedings of the first international symposium on Arctic geology held in Calgary, Alberta, Fanuary ${ }_{1} 1-13$, I96o. Toronto, University of Toronto Press, Vol. 2, p. 833-47.)

Paschinger, V. I912. Die Schneegrenze in verschiedenen Klimaten. Dr A. Petermanns Mitteilungen aus Justus Perthes' Geographischer Anstalt, Vol. 37, Ergänzungsht. Nr. I73.

Porter, S. C. I 964 . Composite Pleistocene snow line of Olympic Mountains and Cascade Range, Washington. Geological Society of America. Bulletin, Vol. 75, No. 5, p. 477-81.

Reeves, C. C., jr. I965[a]. Chronology of west Texas pluvial lake dunes. Fournal of Geology, Vol. 73, No. 3, p. 504-08.

Reeves, C. C., jr. 1965[b]. Pleistocene climate of the Llano Estocado. Fournal of Geology, Vol. 73, No. I, p. 181-89.

Roscoe, J. T. 1975. Fundamental research statistics for the behavioral sciences. Second edition. New York, etc., Holt, Rinehart, and Winston, Inc. (International Series on Division Processes.) 